\title{
Remarkable inhibitory effects of hybrid liposomes on growth of human colon cancer cells through induction of cell cycle arrest along with apoptosis
}

This article was published in the following Dove Press journal:

International Journal of Nanomedicine

7 September 2011

Number of times this article has been viewed

Yuji Komizu

Hidetsugu Ueoka

Koichi Goto

Ryuichi Ueoka

Division of Applied Life Science, Graduate School of Engineering, Sojo University, Ikeda, Kumamoto, Japan
Correspondence: Ryuichi Ueoka Division of Applied Life Science, Graduate School of Engineering, Sojo University, 4-22-I Ikeda, Kumamoto 860-0082, Japan

$\mathrm{Tel}+8 \mid 963263952$

Fax +81963260522

Email ueoka@life.sojo-u.ac.jp
Background: Hybrid liposomes can be prepared by simply sonicating a mixture of vesicular and micellar molecules in buffer solutions. In this study, we investigated the effects of hybrid liposomes on the growth of human colon cancer cells in vitro.

Methods: Hybrid liposomes (HL-n, $\mathrm{n}=21,23,25$ ) composed of L- $\alpha$-dimyristoylphosphatidylcholine (DMPC) and polyoxyethylene $(n)$ dodecyl ethers $\left(\mathrm{C}_{12}(\mathrm{EO}), \mathrm{n}=21,23,25\right)$ were prepared by the sonication method and their inhibitory effects on growth of human colon cancer HCT116 cells were examined in vitro.

Results: Significant growth inhibition of HCT116 cells was observed in the presence of HL-n. The fifty percent inhibitory concentration $\left(\mathrm{IC}_{50}\right)$ of HL-n was less than half that of DMPC liposomes. Furthermore, fluorescence microscopic and flow cytometric analyses indicated that the markedly inhibitory effects of HL-n on the growth of HCT116 cells could be attained through the induction of cell cycle arrest at the $\mathrm{G}_{0} / \mathrm{G}_{1}$ phase along with apoptotic cell death.

Conclusion: It was found for the first time that HL-n can induce both cell cycle arrest and apoptosis in colon cancer cells. The findings in this study should contribute to novel chemotherapy for colon cancer.

Keywords: hybrid liposome, colon cancer cell, cell cycle arrest, apoptosis

\section{Introduction}

Colorectal cancer is one of the most malignant neoplasms in the world and develops in the cecum, colon and rectum. ${ }^{1}$ Generally, patients with tumoral tissues confined within the intestinal wall are curable by enucleation of the local lesions. However, when the tumors are enlarged and advanced into the deeper regions, it is difficult to cure cases with surgical treatment. ${ }^{2}$ Although chemotherapy with anticancer drugs, such as 5-fluorouracil, leucovorin, irinotecan, and oxaliplatin, can prolong survival, this therapy may not effect a complete cure for the metastatic carcinoma. ${ }^{2,3}$ Therefore, a new remedy for cancer is urgently needed.

Hybrid liposomes, first developed by Ueoka et al, ${ }^{4}$ can be prepared by simply sonicating a mixture of vesicular and micellar molecules in buffer solutions. Inhibitory effects of hybrid liposomes composed of L- $\alpha$-dimyristoylphosphatidylcholine (DMPC) and polyoxyethylene(20) sorbitan monolaurate (Tween 20) including antitumor drugs such as 1,3-bis(2-chloroethyl)-1-nitrosourea on the growth of glioma cells in vitro and in vivo have been observed..$^{5}$ On the other hand, hybrid liposomes composed of DMPC and polyoxyethylene $(n)$ alkyl ethers without any drugs demonstrated remarkable inhibitory effects on the growth of various tumor cells in vitro ${ }^{6-8}$ and in vivo. ${ }^{9-12}$ In addition, it has been 
demonstrated that hybrid liposomes could induce apoptotic cell death in leukemia, ${ }^{13}$ hepatoma, ${ }^{7}$ lung cancer, ${ }^{14}$ breast cancer, ${ }^{8}$ and primary effusion lymphoma cells. ${ }^{15}$ With respect to colon cancer cell lines, hybrid liposomes induced apoptosis in human colon adenocarcinoma $\mathrm{WiDr}^{16}$ and mouse colon carcinoma Colon 26 cells in vitro. ${ }^{17}$ Furthermore, we also reported that hybrid liposomes distinguished between normal colon CCD33Co cells and tumor colon WiDr cells, then fused and accumulated into the plasma membranes of tumor cells, leading to apoptosis. More recently, it was observed that hybrid liposomes could inhibit growth of cholangiocarcinoma cells through induction of cell cycle arrest. ${ }^{18}$ However, research concerning the effects of hybrid liposomes on the cell cycle of cancer cells is very limited.

In this study, we investigated the effects of hybrid liposomes (HL-n, $\mathrm{n}=21,23,25)$ composed of DMPC and polyoxyethylene $(n)$ dodecyl ethers $\left(\mathrm{C}_{12}(\mathrm{EO})_{\mathrm{n}}, \mathrm{n}=21,23\right.$, 25 ) on the growth of human colon cancer (HCT116) cells in vitro, and found significant inhibitory effects on growth of HCT116 cells through induction of cell cycle arrest at the $\mathrm{G}_{0} / \mathrm{G}_{1}$ phase along with apoptotic cell death.

\section{Materials and methods}

\section{Preparation of hybrid liposomes}

Hybrid liposomes (HL-n, $n=21,23,25$ ) were prepared by the following methods. ${ }^{14}$ DMPC (NOF, Tokyo, Japan) and polyoxyethylene $(n)$ dodecyl ethers $\left(\mathrm{C}_{12}(\mathrm{EO})_{\mathrm{n}}, \mathrm{n}=21,23,25\right)$ $\left(\mathrm{C}_{12}(\mathrm{EO})_{21}\right.$ and $\mathrm{C}_{12}(\mathrm{EO})_{25}$; Nikko Chemicals, Tokyo, Japan, $\mathrm{C}_{12}(\mathrm{EO})_{23}$; Sigma Chemicals, St Louis, MO) were mixed in $5 \%$ glucose solution and sonicated with a bath type sonicator (VS-N300, Velvo-Clear, Tokyo, Japan) at $45^{\circ} \mathrm{C}$ under a nitrogen atmosphere with $300 \mathrm{~W}$, followed by filtration with a $0.20 \mu \mathrm{m}$ filter. The liposomes composed of DMPC were prepared in the same manner as described above.

\section{Dynamic light scattering method}

The size of the HL-n was measured with an electrophoretic light scattering spectrophotometer (ELS-8000, Otsuka Electronics, Hirakata, Japan). ${ }^{13}$ Using a He-Ne laser as the light source, a $633 \mathrm{~nm}$ laser line with $10 \mathrm{~mW}$ power was applied with a scattering angle of $90^{\circ}$. The hydrodynamic diameter $\left(d_{\text {hy }}\right)$ of the HL-n was calculated by the Stokes-Einstein equation $\left(d_{\text {hy }}=k T /(3 \pi \eta D)\right.$, where $k$ is Boltzmann's constant, $T$ is the absolute temperature, $\eta$ is the viscosity of solvent, and $D$ is the diffusion coefficient).

\section{Cell culture}

Human colon cancer HCT116 cell lines were purchased from the American Type Culture Collection (Manassas, VA).
HCT116 cells were maintained in RPMI-1640 medium (Gibco, Gaithersburg, MD) supplemented with penicillin $100 \mathrm{U} / \mathrm{mL}$, streptomycin $50 \mu \mathrm{g} / \mathrm{mL}$, and $10 \%$ fetal bovine serum (HyClone Laboratories, Logan, UT). The cells were cultured in a $5 \% \mathrm{CO}_{2}$ humidified incubator at $37^{\circ} \mathrm{C}$.

\section{WST-I assay}

The inhibitory effects of HL-n on the growth of HCT116 cells were examined on the basis of a WST-1 (2-methoxy-4-nitrophenyl-3-(4-nitrophenyl)-5-(2,4-disulfophenyl)-2H-tetrazolium, monosodium salt) assay. ${ }^{12}$ HCT116 cells were seeded at a density of $2.0 \times 10^{3}$ cells per well in 96-well plates (Sumitomo Bakelite, Tokyo, Japan) and incubated in a humidified atmosphere of 5\% $\mathrm{CO}_{2}$ at $37^{\circ} \mathrm{C}$. After 24 hours, HL-n were added into each well and the plates were incubated for 48 hours. The viable cell number was measured with a Cell Counting Kit (Dojindo Laboratories, Kumamoto, Japan) according to the manufacturer's instructions, and the $\mathrm{IC}_{50}$ of HL-n was determined from the concentrationdependence of the viable cell number.

\section{Annexin- $V$ labeling assay}

Phosphatidylserines exposed on the outer plasma membranes of apoptotic HCT116 cells were detected by Annexin-V labeling assay. ${ }^{19}$ HCT116 cells were seeded at a density of $4.0 \times 10^{3}$ cells in glass bottom dishes (Mat Tek, Flint, MI) in a humidified atmosphere of $5 \% \mathrm{CO}_{2}$ at $37^{\circ} \mathrm{C}$. After 24 hours, HL-n were added at the $\mathrm{IC}_{50}$ values and the dishes were incubated for 3 hours. Subsequently, the cells were washed with phosphate-buffered saline and dyed with an Annexin-VFLUOS staining kit (Roche Diagnostics, Basel, Switzerland). Briefly, the cells were treated with $2 \mu \mathrm{L}$ of FLUOS-conjugated Annexin-V and $2 \mu \mathrm{L}$ of propidium iodide stock solutions. After incubation for 10 minutes at room temperature, the cells were observed using a confocal laser microscope (TCS-SP, Leica, Germany) with a $75 \mathrm{~mW}$ Ar laser (Annexin-V, excitation $/$ detection $=488 \mathrm{~nm} / 500-550 \mathrm{~nm}$; propidium iodide, excitation/detection $=488 \mathrm{~nm} / 620-720 \mathrm{~nm}$ ).

\section{TUNEL method}

DNA fragmentations in apoptotic HCT116 cells were detected by the TUNEL (terminal deoxynucleotidyl transferase-mediated dUTP-biotin nick end labeling) method. ${ }^{10}$ HCT 116 cells were seeded at a density of $4.0 \times 10^{3}$ cells in glass bottom dishes in a humidified atmosphere of $5 \% \mathrm{CO}_{2}$ at $37^{\circ} \mathrm{C}$. After 24 hours, HL-n were added at the $\mathrm{IC}_{50}$ and the dishes were incubated for 48 hours. The cells were then fixed with a $4 \%$ paraformaldehyde solution and stained using an in situ cell death detection kit (Roche Diagnostics) according to the manufacturer's 
recommendations. The stained cells were observed using a confocal laser microscope with an Ar laser (TUNEL, excitation/detection $=488 \mathrm{~nm} / 500-550 \mathrm{~nm}$ ) and a He-Ne laser (TOPRO-3, excitation/detection $=633 \mathrm{~nm} / 650-740 \mathrm{~nm})$.

\section{Flow cytometry}

Cell cycle analysis of HCT116 cells was performed with a flow cytometer (Epics XL system II, Beckman Coulter, Fullerton, CA). ${ }^{13,16}$ HCT116 cells were seeded at a density of $2.0 \times 10^{3}$ cells per well in 6-well plates (Sumitomo Bakelite) and incubated in a humidified atmosphere of $5 \% \mathrm{CO}_{2}$ at $37^{\circ} \mathrm{C}$. After 24 hours, HL-n were added into each well and the plates were incubated for 48 hours. After treatment with trypsin, the cells were centrifuged at $200 \times \mathrm{g}$ for 5 minutes, washed with phosphate-buffered saline, and resuspended in phosphatebuffered saline containing $40 \mu \mathrm{g} / \mathrm{mL}$ propidium iodide, $1 \mathrm{mg} /$ $\mathrm{mL}$ RNase, and $0.1 \%$ Triton $\mathrm{X}-100$ in a dark room. The DNA contents of the cells were then analyzed using a flow cytometer with a single excitation $488 \mathrm{~nm}$ of $15 \mathrm{~mW}$ Ar laser. The propidium iodide signal was detected by FL3 sensor at $605-635 \mathrm{~nm}$ and the data were analyzed on WinMDI (v 2.8; The Scripps Research Institute, Flow Cytometry Core Facility, La Jolia, CA) software.

\section{Enzyme immunometric assay}

Expression of p21 WAF1/CIP1 in HCT116 cells was analyzed by an enzyme immunometric assay. ${ }^{20}$ HCT116 cells were seeded at a density of $2.0 \times 10^{3}$ cells per well in 6 -well plates and incubated in a humidified atmosphere of $5 \% \mathrm{CO}_{2}$ at $37^{\circ} \mathrm{C}$. After 24 hours, HL-23 were added at $200 \mu \mathrm{M}$ and the plates were incubated for 48 hours. After treatment with trypsin, the cells were centrifuged at $200 \times \mathrm{g}$ for 5 minutes, washed with phosphate-buffered saline, and resuspended in cell lysis buffer solution containing $50 \mathrm{mM}$ Tris $\mathrm{HCl}, \mathrm{pH} 7.4$, $150 \mathrm{mM} \mathrm{NaCl}, 1 \mathrm{mM}$ EDTA, $1 \mathrm{mM}$ EGTA, $1 \%$ Triton X-100, $1 \%$ sodium deoxycholate, and $0.1 \%$ sodium dodecyl sulfate. Then, p21 WAF1/CIP1 in the cell lysates was assayed using a TiterZyme ${ }^{\circledR}$ EIA human p21 enzyme immunometric assay kit (Assay Designs, Ann Arbor, MI) according to the manufacturer's recommendations.

\section{Results and discussion}

The hybrid liposomes were prepared by sonication of a mixture containing $90 \mathrm{~mol} \%$ DMPC and $10 \mathrm{~mol}^{\%} \mathrm{C}_{12}(\mathrm{EO})_{\mathrm{n}}$ $(\mathrm{n}=21,23,25)$ in $5 \%$ glucose solutions, and the morphology of HL-n was measured by the dynamic light scattering method. The results are shown in Figure 1. The diameters $\left(d_{\text {hy }}\right)$ of the HL-n were about $40 \mathrm{~nm}$ with a narrow range in the
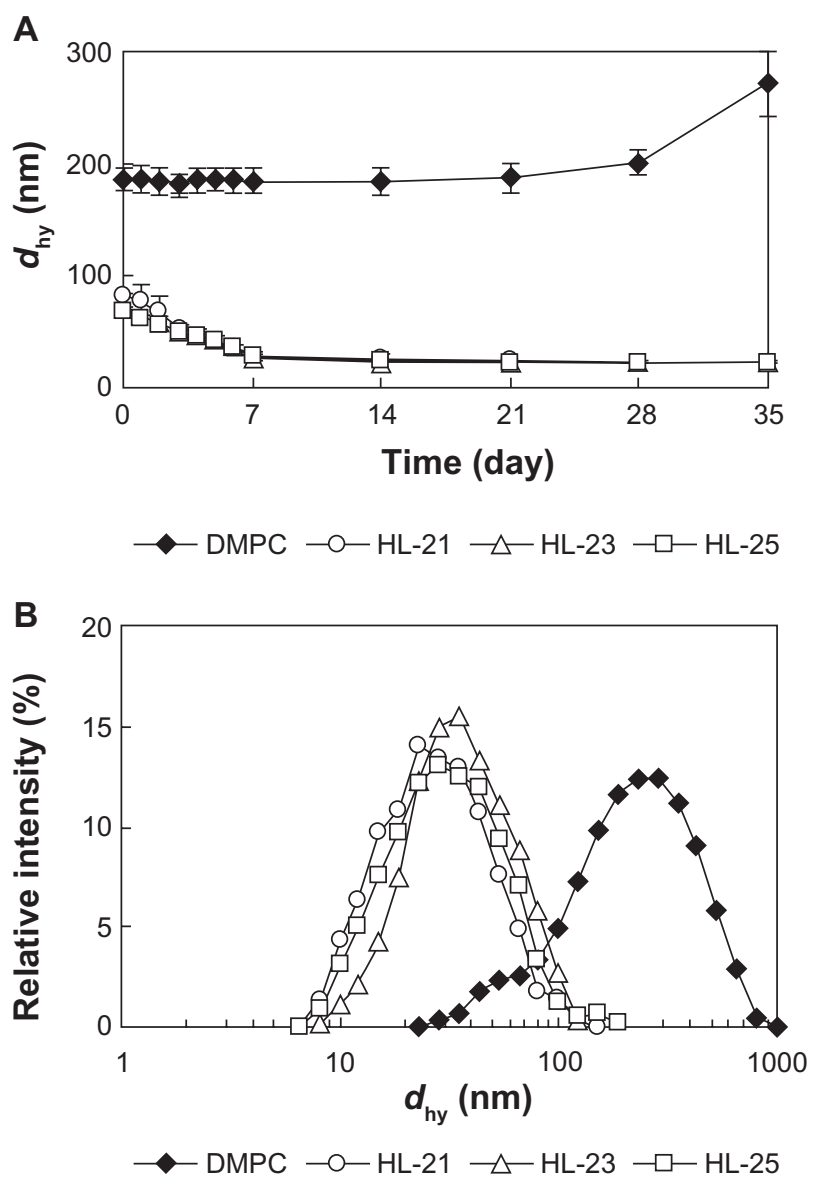

Figure I Time course of $d_{\text {hy }}$ change (A) and the size distribution (B) of HL-n. HL-n $(n=21,23,25)$ were prepared by sonication of a mixture containing DMPC and $C_{12}(E O)_{n}$ using a bath type sonicator in $5 \%$ glucose solution. The diameter $\left(d_{h y}\right)$ of HL-n was measured by a dynamic light scattering method using an electrophoretic light scattering spectrophotometer at $25^{\circ} \mathrm{C}$. Data are the mean \pm standard error of the mean $(n=3)$ from three independent experiments. $[D M P C]=10 \mathrm{mM},\left[\mathrm{C}_{12}(E O)_{n}\right]=1.1 \mathrm{mM}$. Abbreviations: DMPC, dimyristoylphosphatidylcholine; $\mathrm{HL}$, hybrid liposomes.

size distribution and remained stable for more than 1 month, whereas that of liposomes composed of only DMPC were about $200 \mathrm{~nm}$ in diameter. This suggested that HL-n less than $100 \mathrm{~nm}$ in diameter could avoid clearance by the reticular endothelial system in vivo. ${ }^{21}$

First, we examined the inhibitory effects of HL- $n(n=21$, $23,25)$ on the growth of colon cancer HCT116 cells in vitro on the basis of WST-1 assay. The number of viable HCT116 cells was evaluated in the absence or in the presence of different concentrations of HL-n by WST-1, and the $\mathrm{IC}_{50}$ of HL-n was determined from the concentration-dependence of the viable cell number (Supplementary Figure S1). In Figure 2, the $\mathrm{IC}_{50}$ value is the concentration of HL-n necessary to inhibit the growth of HCT116 cells by half. The $\mathrm{IC}_{50}$ values were $0.190 \mathrm{mM}$ DMPC for HL-21, $0.183 \mathrm{mM}$ DMPC for HL-23, and 0.202 mM DMPC for HL-25. On the other hand, the $\mathrm{IC}_{50}$ of DMPC liposomes was $0.477 \mathrm{mM}$ and the value 


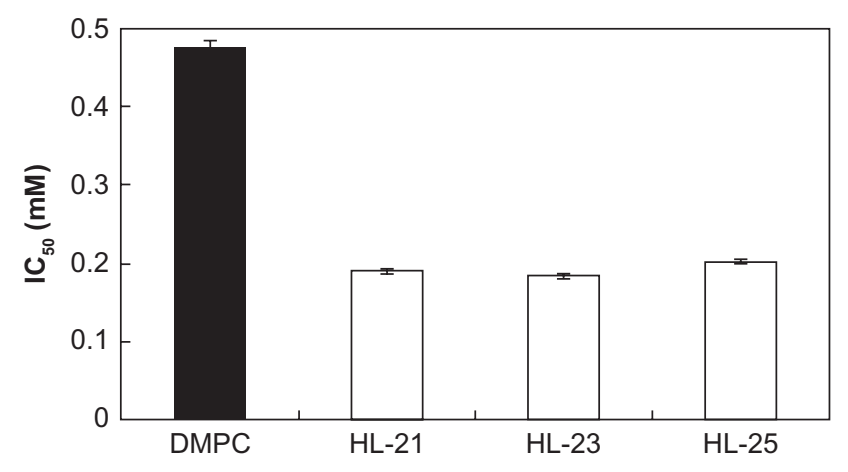

Figure $2 \mathrm{IC}_{50}$ of $\mathrm{HL}-\mathrm{n}$ on the growth of HCTII 6 cells in vitro. Inhibitory effects of HL-n $(n=21,23,25)$ on the growth of HCTII 6 cells were examined on the basis of WST-I assay. Fifty percent inhibitory concentration $\left(\mathrm{IC}_{50}\right)$ of $\mathrm{HL}-\mathrm{n}$ was determined from the concentration-dependence for the viable cell number of HCTII6 cells incubated in the presence of HL- $n$ for 48 hours. Data are the mean \pm standard error of the mean $(n=3)$ from three independent experiments.

Abbreviations: DMPC, dimyristoylphosphatidylcholine; HL, hybrid liposomes; IC ${ }_{50}$, 50 percent inhibitory concentration.

was more than twice those of HL-n. These results indicate that HL-n should be effective for inhibiting the growth of HCT116 cells as well as in the case of other colon cancer cell lines. ${ }^{16,17}$ Hybrid liposomes being more fluid as compared with DMPC liposomes showed strong inhibitory effects on the growth of human colon cancer (WiDr) cells ${ }^{16}$ and human leukemia cells. ${ }^{12}$ The strong inhibitory effects on the growth of HCT116 cells should be closely related to the membrane fluidity of HL-n.

Second, we examined the induction of apoptosis by HL-n in HCT116 cells with a confocal laser microscope. It is well known that the redistribution of phosphatidylserines from the inner to outer leaflet of the plasma membrane is a hallmark of early apoptotic cells. Therefore, HCT116 cells were treated with HL-n for 3 hours and observed by the Annexin-V/propidium iodide dual staining method. The double staining assay with Annexin-V and propidium iodide $^{19,22}$ detects early apoptotic and necrotic cells as green and red fluorescent cells, respectively. The fluorescence micrographs of HCT116 cells treated with HL-n are shown in Figure 3A. Green fluorescence was observed at the plasma membranes of HCT116 cells after treatment with HL-n, although no green fluorescence was observed in the case of DMPC liposomes. No red fluorescent cells were observed in HCT116 cells treated with HL-n, suggesting that HL-n did not induce necrosis in HCT116 cells. On the other hand, the latter apoptotic cells are characterized by increased plasma membrane permeability and fragmentation of nuclear DNA. Using the TUNEL method, we observed the DNA fragmentation of HCT116 cells treated with HL-n for 48 hours. The fluorescence micrographs are shown in Figure 3B. The nuclei of all cells were stained by TOPRO-3 and exhibited red fluorescence. As regards TUNEL staining, green or orange (overlay) fluorescence was observed in cells treated with HL-n, indicating the presence of nuclear condensation and fragmentation in apoptotic cells. In contrast, green (or orange) fluorescence in HCT116 cells was not observed in the case of DMPC liposomes. These observations demonstrated induction of apoptotic cell death toward HCT116 cells by HL-n. It has been already elucidated that hybrid liposomes induce apoptosis in various tumor cells, with activations of caspases-3, -8 , and -9 , and reduction of mitochondria membrane potential. ${ }^{8,11-13,16}$ HL-n could probably fuse and accumulate into HCT116 cells, and induce apoptosis through activation of caspase cascades.

In order to gain further insight into the mechanism of inhibitory effects of HL-n on growth of HCT116 cells, we performed a cell cycle analysis of HCT116 cells treated with HL-n by flow cytometry. The results are shown in Figure $4 \mathrm{~A}$. After treatment with $\mathrm{HL}-\mathrm{n}, \mathrm{G}_{0} / \mathrm{G}_{1}$ populations of HCT116 cells gradually increased with the decrease of $\mathrm{S}$ and $\mathrm{G}_{2} / \mathrm{M}$ populations in the lower concentration range $([D M P C]=0-0.2 \mathrm{mM})$. Interestingly, $\mathrm{G}_{0} / \mathrm{G}_{1}$ populations of HCT116 cells gradually decreased with the increase in sub- $\mathrm{G}_{1}$ populations in the higher concentration range $([\mathrm{DMPC}]=0.2-0.5 \mathrm{mM})$. These results indicate that HL-n should arrest the cell cycle progression of HCT116 cells at the $\mathrm{G}_{0} / \mathrm{G}_{1}$ phase at the lower concentrations and induce apoptosis of HCT116 cells at the higher concentrations. In regard to induction of cell cycle arrest by HL-n, we examined the regulatory protein $\mathrm{p} 21 \mathrm{WAF} 1 / \mathrm{CIP} 1$, which play a key role in regulating entry of cells at the $\mathrm{G}_{1} / \mathrm{S}$ transition check point, ${ }^{23}$ in HCT 116 cells by an enzyme immunometric assay. As shown in Figure 4B, a significant increase in p21 WAF1/CIP1 was observed in HCT 116 cells at 48 hours after the treatment with HL-23 $([\mathrm{DMPC}]=0.2 \mathrm{mM})$. This result suggests that hybrid liposome-mediated $\mathrm{G}_{0} / \mathrm{G}_{1}$ arrest of HCT116 cells was associated with upregulation of $\mathrm{p} 21$ WAF1/CIP1 protein. With respect to cell cycle regulation, some studies have reported that cell cycle arrest is closely associated with metabolic events in plasma membranes. ${ }^{24-27}$ Although the mechanistic details are not yet clear, it seems that HL-n could accumulate in plasma membranes of HCT116 cells, change the membrane characteristics related to cell cycle progression, and induce $\mathrm{G}_{0} / \mathrm{G}_{1}$ phase arrest. On the other hand, $\mathrm{G}_{0} / \mathrm{G}_{1}$ phase arrest was also observed for HCT116 cells treated with DMPC liposomes, that is, the $\mathrm{G}_{0} / \mathrm{G}_{1}$ population of HCT116 cells increased with the decrease in $\mathrm{S}$ and $\mathrm{G}_{2} / \mathrm{M}$ populations in a dose-dependent manner. However, the sub- $\mathrm{G}_{1}$ population of HCT116 cells was not detected in the whole concentration 

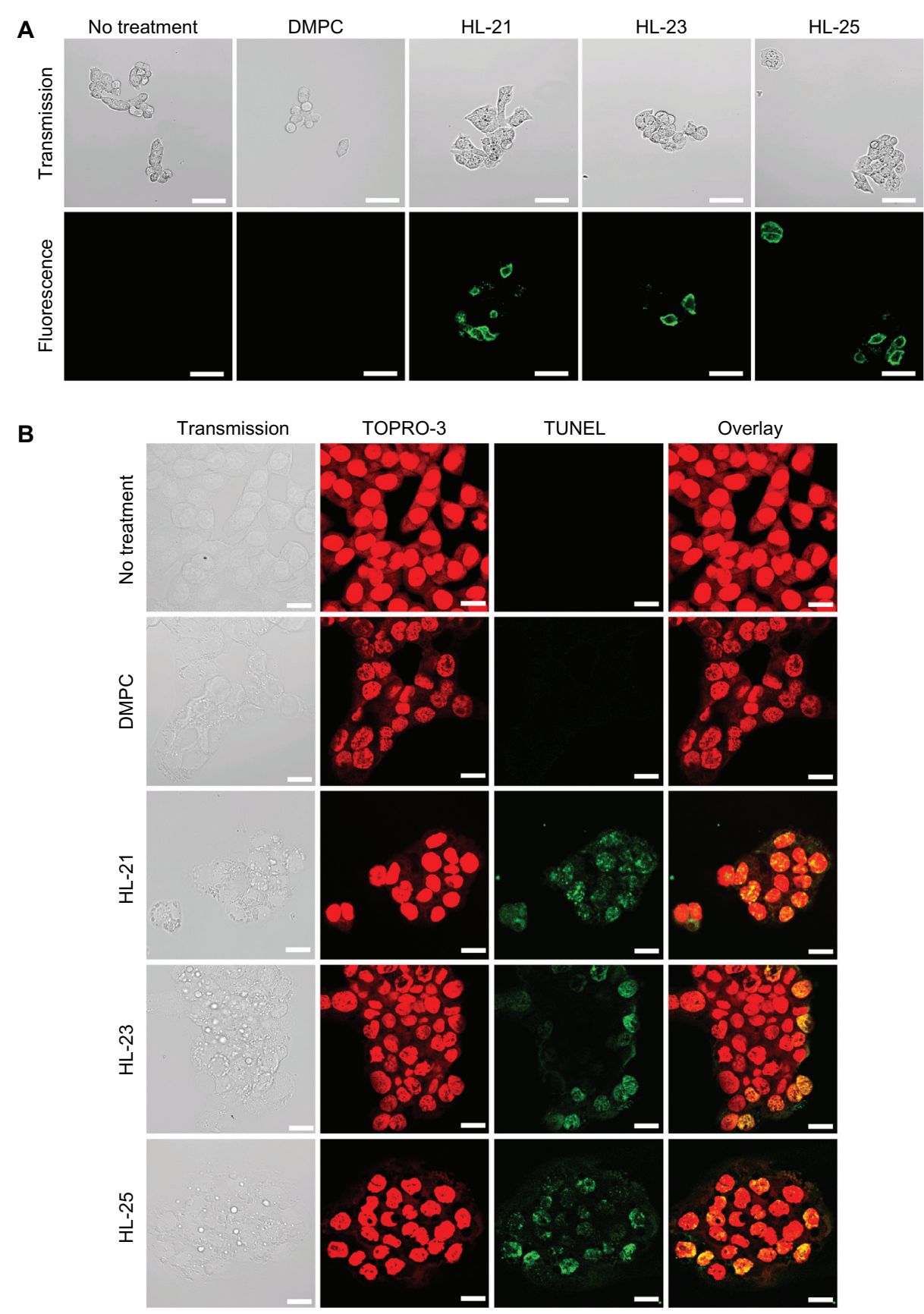

Figure 3 Induction of apoptosis in HCTII 6 cells by HL-n. (A) Fluorescence micrographs of HCTII 6 cells stained with FLUOS-conjugated Annexin-V and propidium iodide after the treatment with HL-n $(n=21,23,25)$ for 3 hours. (B) Fluorescence micrographs of HCTII 6 cells stained with TUNEL and TOPRO-3 after the treatment with HL- $n$ $(\mathrm{n}=2 \mathrm{I}, 23,25)$ for 48 hours. In both experiments, HCTII 6 cells were treated with HL-n at the IC ${ }_{50}$ (DMPC liposomes; [DMPC] = 0.477 mM, HL-2I; [DMPC] = 0.190 mM, $\mathrm{HL}-23 ;[\mathrm{DMPC}]=0.183 \mathrm{mM}, \mathrm{HL}-25 ;$ [DMPC] $=0.202 \mathrm{mM})$.

Note: Scale bar; $20 \mu \mathrm{m}$.

Abbreviations: DMPC, dimyristoylphosphatidylcholine; HL, hybrid liposomes; $\mathrm{IC}_{50}, 50$ percent inhibitory concentration.

range $([\mathrm{DMPC}]=0-0.5 \mathrm{mM})$ in this study. These results in relation to the cell cycle were in good agreement with the observations for apoptotic HCT116 cells by fluorescence microscopy. In our previous study, we reported that HL-n elicited $\mathrm{G}_{1}$ phase cell cycle arrest of human cholangiocarcinoma cells, although HL-n did not induce apoptosis toward cholangiocarcinoma cells. ${ }^{18}$ In this study, we have found for the first time that inhibitory effects of HL-n on the growth of HCT116 cells could be caused by induction of cell cycle arrest at the $\mathrm{G}_{0} / \mathrm{G}_{1}$ phase along with apoptotic cell death.

As mentioned above, markedly inhibitory effects of HL-n on growth of human colon cancer HCT116 cells in vitro were obtained in this study. It is noteworthy that induction of cell cycle arrest along with apoptosis with HL-n could 

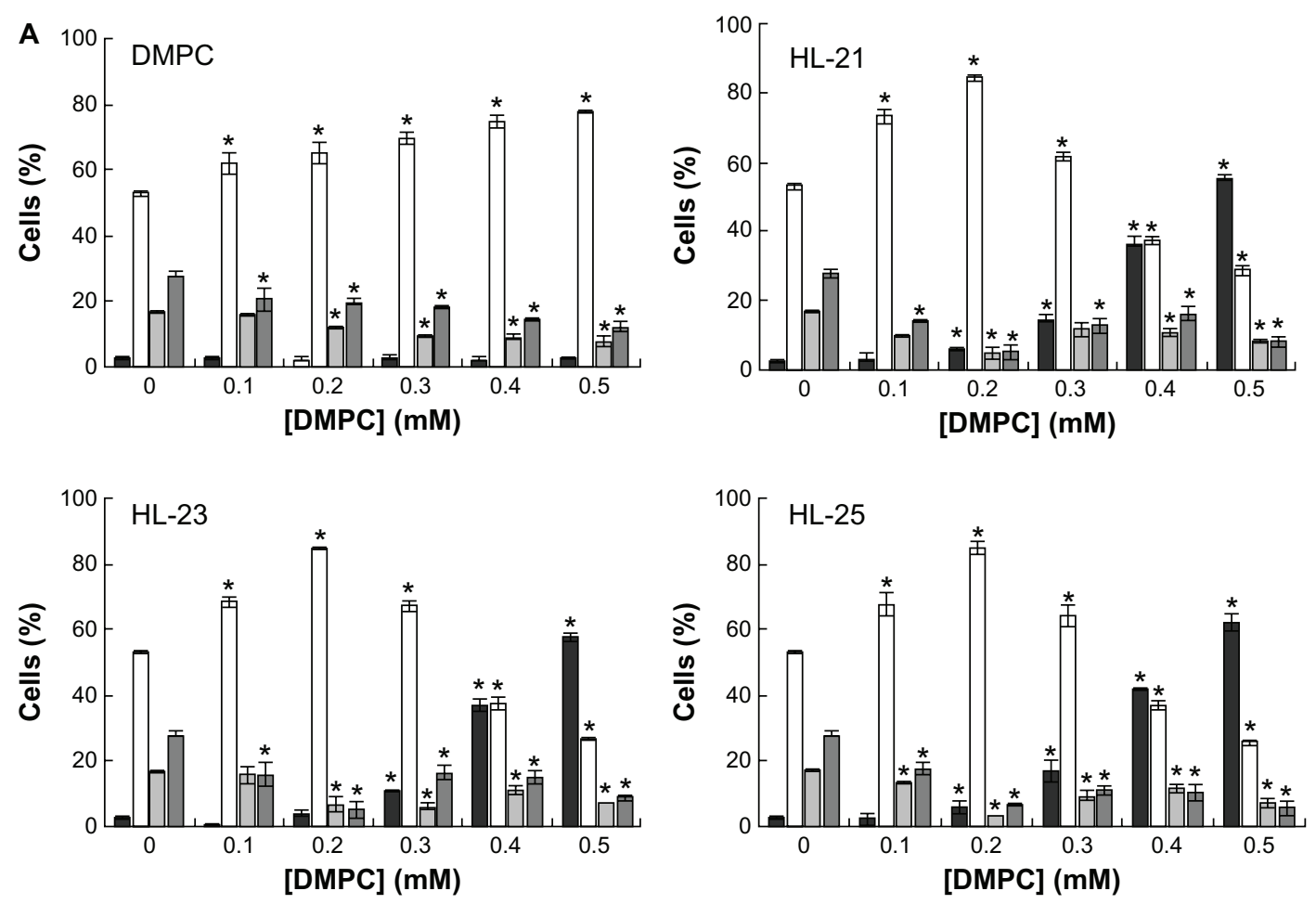

$\square$ Sub-G $\quad \square G_{0} / G_{1}$

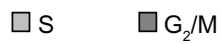

B

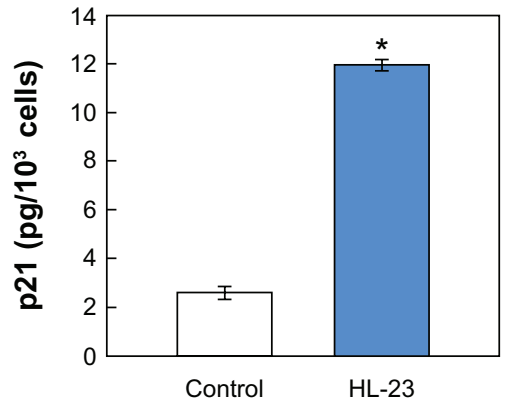

C

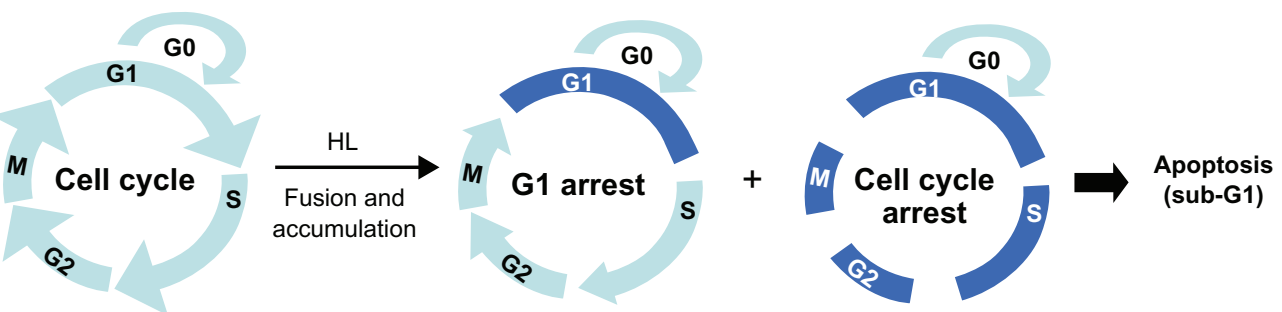

Figure 4 Cell cycle analysis of HCTII6 cells treated with HL-n. (A) Cell cycle analysis of HCTII6 cells was performed by flow cytometry. HCTII6 cells were incubated in the presence of $\mathrm{HL}-\mathrm{n}(\mathrm{n}=2 \mathrm{I}, 23,25)$ at the $\mathrm{IC}_{50}$ for 48 hours. DNA contents in HCTII6 were analyzed using a flow cytometer. ${ }^{2}(\mathbf{B})$ Expression of $\mathrm{p} 2 \mathrm{I}$ WAFI/CIPI in $\mathrm{HCTI} 16$ cells treated with HL-23. HCTI 16 cells were incubated in the presence or absence (control) of HL-23 ([DMPC] $=0.2 \mathrm{mM}$ ) for 48 hours and p2I expression was determined by enzyme immunometric assay. ${ }^{\mathrm{b}}(\mathbf{C})$ Schematic representation of cell cycle arrest and apoptosis in cancer cells induced by HL-n.

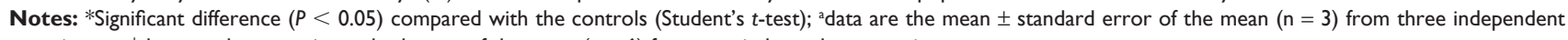
experiments; bdata are the mean \pm standard error of the mean $(n=6)$ from two independent experiments.

Abbreviations: DMPC, dimyristoylphosphatidylcholine; HL, hybrid liposomes.

play an important role in growth inhibition of HCT116 cells (Figure 4C). Deviation from the normal cell cycle and the resistance to apoptosis lie at the heart of tumor development. ${ }^{28}$ This study suggests that HL-n could be an effective chemotherapeutic agent for colon cancer in the near future.

\section{Conclusion}

In conclusion, we have clearly demonstrated the inhibitory effects of hybrid liposomes composed of DMPC and $\mathrm{C}_{12}(\mathrm{EO})_{\mathrm{n}}$ on growth of human colon cancer HCT116 cells in vitro. The noteworthy aspects are as follows. The diameters 
of the HL-n were less than $100 \mathrm{~nm}$ and remained stable for more than 1 month. The markedly inhibitory effects of HL-n on growth of HCT116 cells were obtained. $\mathrm{IC}_{50}$ values of HL-n were less than half of that of DMPC liposomes. The inhibitory effects of HL-n on the growth of HCT116 cells were attained through induction of cell cycle arrest at $\mathrm{G}_{0} / \mathrm{G}_{1}$ phase along with apoptotic cell death. It is worthy of note that HL-n can induce both cell cycle arrest and apoptosis in colon cancer cells. The results of this study should contribute to novel chemotherapy for colon cancer.

\section{Acknowledgments}

The technical assistance of Ms Yoko Tomita and Dr Mamiko Yukihara with this research was appreciated. This work was supported in part by a Grant-in-Aid for Science Research from the Ministry of Education, Science and Culture of Japan.

\section{Disclosure}

The authors have no conflicts of interest in this work.

\section{References}

1. Danaei G, Van der Hoorn S, Lopez AD, Murray CJL, Ezzati M. The comparative risk assessment collaborating group (cancers), causes of cancer in the world: Comparative risk assessment of nine behavioural and environmental risk factors. Lancet. 2005;366(9499):1784-1793.

2. Scheele J, Altendorf-Hofmann A. Resection of colorectal liver metastases. Langenbeck's Arch Surg. 1999;384(4):313-327.

3. Goldberg RM, Sargent DJ, Morton RF, et al. A randomized controlled trial of fluorouracil plus leucovorin, irinotecan, and oxaliplatin combinations in patients with previously untreated metastatic colorectal cancer. J Clin Oncol. 2004;22(1):23-30.

4. Ueoka R, Matsumoto Y, Moss RA, et al. Membrane matrix for the hydrolysis of amino acid esters with marked enantioselectivity. $J \mathrm{Am}$ Chem Soc. 1988;110(5):1588-1595.

5. Kitamura I, Kochi M, Matsumoto Y, Ueoka R, Kuratsu J, Ushio Y. Intrathecal chemotherapy with 1,3-bis(2-chloroethyl)-1-nitrosourea encapsulated into hybrid liposomes for meningeal gliomatosis: An experimental study. Cancer Res. 1996;56(17):3986-3992.

6. Matsumoto $Y$, Imamura $C$, Ito $T$, Taniguchi $C$, Ueoka R. Specific hybrid liposomes composed phosphatidylcholine and polyoxethlenealkyl ether with markedly enhanced inhibitory effects on the growth of tumor cells in vitro. Biol Pharm Bull. 1995;18(10):1456-1458.

7. Nakano K, Iwamoto Y, Takata W, Matsumoto Y, Ueoka R. Specific accumulation and growth inhibitory effects of hybrid liposomes to hepatoma cells in vitro. Bioorg Med Chem Lett. 2002;12(22): 3251-3254.

8. Nagami H, Matsumoto Y, Ueoka R. Induction of apoptosis by hybrid liposomes for human breast tumor cells along with activation of caspases. Biol Pharm Bull. 2006;29(2):380-381.

9. Ueoka R, Matsumoto Y, Ichihara H, Kiyokawa T. Chemotherapy with hybrid liposomes composed of dimyristoylphosphatidylcholine and polyoxyethylenealkyl ether without drugs. In: Marten MR, Park TH, Nagamune T, editors. Biological Systems Engineering (ACS Symposium Series). Washington, DC: American Chemical Society; 2002.
10. Ichihara H, Nagami H, Kiyokawa T, Matsumoto Y, Ueoka R. Chemotherapy using hybrid liposomes along with induction of apoptosis. Anticancer Res. 2008;28(2B):1187-1195.

11. Shimoda S, Ichihara H, Matsumoto Y, Ueoka R. Chemotherapy with hybrid liposomes for human breast tumors along with apoptosis in vivo. Int J Pharm. 2009;372(1-2):162-168.

12. Matsumoto Y, Iwamoto Y, Matsushita T, Ueoka R. Novel mechanism of hybrid liposomes-induced apoptosis in human tumor cells. Int J Cancer. 2005;115(3):377-382.

13. Iwamoto Y, Matsumoto Y, Ueoka R. Induction of apoptosis of human lung carcinoma cells by hybrid liposomes containing polyoxyethylenedodecyl ether. Int J Pharm. 2005;292(1-2):231-239.

14. Towata T, Komizu Y, Suzu S, Matsumoto Y, Ueoka R, Okada S. Hybrid liposomes inhibit the growth of primary effusion lymphoma in vitro and in vivo. Leuk Res. 2010;34(7):906-911.

15. Towata T, Komizu Y, Suzu S, Ueoka R, Okada S. Highly selective fusion and accumulation of hybrid liposomes into primary effusion lymphoma cells along with induction of apoptosis. Biochem Biophys Res Commun. 2010;393(3):445-448.

16. Komizu Y, Matsumoto Y, Ueoka R. Membrane targeted chemotherapy with hybrid liposomes for colon tumor cells leading to apoptosis. Bioorg Med Chem Lett. 2006;16(23):6131-6134.

17. Funamoto K, Ichihara H, Matsushita T, Matsumoto Y, Ueoka R. Marked therapeutic effects of hybrid liposomes on the hepatic metastasis of colon carcinoma. Yakugaku Zasshi. 2009;129(4): 464-473. Japanese.

18. Towata T, Komizu Y, Suzu S, et al. Hybrid liposomes inhibit the growth of cholangiocarcinoma by induction of cell cycle arrest in $\mathrm{G}_{1}$ phase. Bioorg Med Chem Lett. 2010;20(12):3680-3682.

19. Van Engeland M, Nieland LJW, Ramakerss FCS, Schutte B, Reutelingsperger CPM. Annexin V-affinity assay: A review on an apoptosis detection system based on phosphatidylserine exposure. Cytometry.1998;31(1):1-9.

20. Hsu YL, Kuo PL, Chiang LC, Lin CC. Isoliquiritigenin inhibits the proliferation and induces the apoptosis of human non-small cell lung cancer A549 cells. Clin Exp Pharmacol Physiol. 2004;31(7): 414-418.

21. Huang SK, Lee KD, Hong K, Friend DS, Papahadjopoulos D. Microscopic localization of sterically stabilized liposomes in colon carcinoma-bearing mice. Cancer Res. 1992;52(19):5135-5143.

22. Vermes I, Hanen C, Steffens-Nakken H, Reutelingsperger C. A novel assay for apoptosis. Flow cytometric detection of phosphatidylserine expression early apoptotic cells using fluorescein labelled Annexin V. J Immunol Methods. 1995;184(1):39-51.

23. Massagué J. G1 cell-cycle control and cancer. Nature. 2004;432(7015): 298-306.

24. Hatten ME, Horwitz AF, Burger MM. The influence of membrane lipids on the proliferation of transformed and untransformed cell lines. Exp Cell Res. 1977;107(1):31-34.

25. Jackowski S. Cell cycle regulation of membrane phospholipid metabolism. J Biol Chem. 1996;271(34):20219-20222.

26. Albino AP, Juan G, Traganos F, et al. Cell cycle arrest and apoptosis of melanoma cells by docosahexaenoic acid: Association with decreased pRb phosphorylation. Cancer Res. 2000;60(15):4139-4145.

27. Zhang XH, Zhao $\mathrm{C}$, Ma ZA. The increase of cell-membranous phosphatidylcholines containing polyunsaturated fatty acid residues induces phosphorylation of p53 through activation of ATR. J Cell Sci. 2007; 120(Pt 23):4134-4143.

28. Evan GI, Vousden KH. Proliferation, cell cycle and apoptosis in cancer. Nature. 2001;411(6835):342-348. 


\section{Supplementary figure}
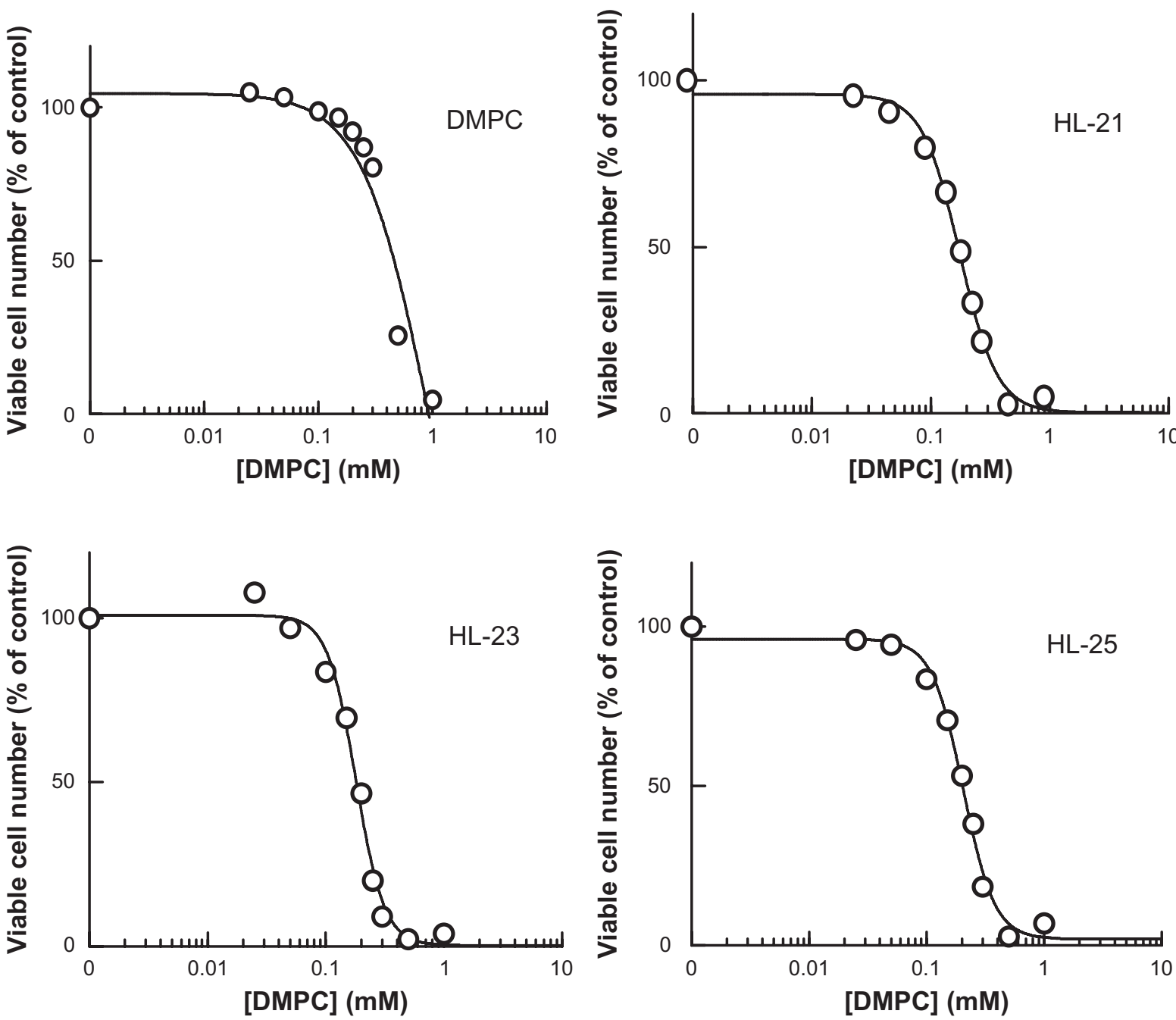

Figure SI Inhibitory effects of HL-n on the growth of HCTI I 6 cells for 48 hours. Abbreviation: DMPC, dimyristoylphosphatidylcholine.

\section{Publish your work in this journal}

The International Journal of Nanomedicine is an international, peerreviewed journal focusing on the application of nanotechnology in diagnostics, therapeutics, and drug delivery systems throughout the biomedical field. This journal is indexed on PubMed Central, MedLine, CAS, SciSearch ${ }^{\circledR}$, Current Contents ${ }^{\circledR} /$ Clinical Medicine,

Journal Citation Reports/Science Edition, EMBase, Scopus and the Elsevier Bibliographic databases. The manuscript management system is completely online and includes a very quick and fair peer-review system, which is all easy to use. Visit http://www.dovepress.com/ testimonials.php to read real quotes from published authors. 